基礎実験を行った.

【方法】人体等価ファントム 2 体を, 患者, 介助者に分け, 頭部CT検 查時を想定して線量評価を行った．撮影条件は $120 \mathrm{kV}, 300 \mathrm{~mA}, 1.0$ 秒, $2 \mathrm{~mm} \times 4$ 検出器 (名目スライス厚 $8 \mathrm{~mm}$ ), $18 \mathrm{scan}$ である. 散乱線 を十分得るため 10 回測定を行い，1回当たりの線量で評価した。介 助者には防護無し, 防護エプロン 2 種類 $(0.25 \mathrm{~mm}$ 鉛相当の含鉛夕イ プと無鉛タイプ)を使用して体表面に40筒所, 200本 (5 本セット)程 度, 熱蛍光線量計 (TLD極光MSO-S) を装着して線量比較を行った。 線量評価は使用管電圧に対して実効エネルギーを算出し，トレーサ ビリティのとれた電離箱と相互比較を行い入射表面線量で評価し た。防護着の防護効果を一般撮影領域のエネルギーで評価した。 【結果】ガントリ近傍の介助では, 線束側で30-50\%線量が増加した. 患者相当のファントム表面線量 (水晶体近傍)， $120 \mathrm{kV}, 300 \mathrm{~mA}$, $1.0 \mathrm{sec}$ で70mGyに対し, 介助者の水晶体は $0.15 \mathrm{mGy}$ 程度であった。防 護着の使用によって胸部, 腹部正面は防護着無しに比べ $1 / 10$ 以下と なった．含鉛夕イプに対して無鉛(軽量)タイプでは，防護効果はや や低くなった，防護衣使用においても線束側で線量が高く，生殖腺 の位置では胸部腹部の表見線量より高くなった．管電圧が高くなる ほど無鉛タイプとの防護効果の差は大きくなった。

118 心カテ診療 $(\mathrm{PCI})$ におけるX線入射ポイント・Peak Skin Dose (PSD) $の$ 検討

新潟大学医歯学総合病院・診療支援部放射線部門 吉村秀太郎

岡 哲也，布施真至，坂井裕則，能登義幸

(株)クロノスメディカルデバイス 佐野耕太郎

(株)R-テック 宮沢正則

【目的】PCIにおける患者皮膚面の被ばく線量の把握はワーキングア ングルが複雑で難しい，前学会の続報として，患者皮膚面のX線入 射ポイントに着目し，PSDすなわち最多線量である第1ピークと， それに次ぐ第 2 ピークのポイントの散布図を分析し, 被ばくの実態 を求めた。

【方法】臨床時PCIで反射型フイルムを使用し, 線量測定と最も被ば く線量が多い第 1 ポイント, 次いで多い第 2 ポイントを座標グラフ で評価する.ささら左右冠動脈別に分類し, その傾向を探求する. なお対象患者は136人(右冠動脈：62, 左冠動脈：74)である.

【結果】PSDの第 1 ピークの散布図で左・右冠動脈全体でみると患者 背面右側 (第 I·IV象限)で58.1\%, 左側 (第II - III象限)で41.9\% と なった。しかし右冠動脈のみでは右側 $82.3 \%$ (I：46.8, IV : 35.5), 左側 $17.7 \%$ (II：4.8, III：12.9) となり, 左冠動脈では右側 $36.5 \%$ (I : 18.9 , IV $: 17.6)$, 左側 $63.5 \%$ (II : 32.4, III $: 31.1)$ となった. 次に第 2 ピークで冠動脈全体をみると右側 $36.3 \%$, 左側 $63.7 \%$ と左右差が見 られた。右冠動脈のみでは右側33.3\% (I：14.0, IV：19.3), 左側66.7 \% (II : 31.6, III : 35.1), 左冠動脈のみでは右側 $38.8 \%$ (I : 19.4, IV : 19.4), 左側61.2\% (II : 40.3, III：20.9) となった。な技実測した 患者皮膚線量は平均でみると第 1 ピークで207.3cGy（右冠動脈： 232.6, 左冠動脈：185.7), 第 2 ピークで56.45cGy (右冠動脈: 52.7 , 左冠動脈：60.2)であった。

119 心血管IVRにおける患者被曝線量：最大皮屇線量の部位に 関する基礎的検討

NTT東日本東北病院·放射線科 布田憲司，新田敏夫，伊藤道明 東北大学. 医学部保健学科放射線技術科学専攻 干田浩一, 洞口正之 東北大学病院·循環器内科 加賀谷豊

東北大学病院・放射線部 梁川 功

東北大学病院·放射線科 高橋昭喜

【日的】X線透視撮影下における心血管IVRにおいて，患者の放射線障 害を防ぐことは極めて重要な問題となっている，患者の放射線障害 回避のためには, 患者最大皮膚線量の把握が必要である. 今回我々
は, 心血管IVRに扔ける, 患者最大皮虐線量の部位と範囲(面積)に ついて，詳細に分析を行ったので報告する。

【方法】約200例の経皮的冠動脈形成術 (PCI) において検討を行った。 心血管造影装置はシーメンスバイコーplus（ディジタルシネ撮影： $15 \mathrm{frames} / \mathrm{s}$, パルス透視：15pulses/s)を使用し，ケアグラフシステム (シーメンス)を用いて, 最大皮膚線量[患者背部における最大線量部 位とその範囲(面積)を含むる測定した。

【結果】PCIにおける患者背面の最大皮膚線量部位と範囲は, ばらつ きが大きく広い分布を示した．しかし，PCIを行った冠動脈(左右) 別に分けて分析すると, 最大皮膚線量部位と範囲には, ある程度の 傾向があると思われた。

【考察】心血管IVRに扔いて患者最大皮虐線量のリアルタイム測定は 極めて難しいのが現状である，今まで心血管IVRに拈ける患者最大 皮䖉線量の部位と範囲について, 詳しく検討した報告はほとんど無 い. 今回の我々の検討結果は, 心血管IVRにおける患者放射線障害 の回避のために, 有用な追加情報を提供できるものと考える.

\section{0 反射型線量測定用フィルムを用いたPCI時の患者皮龐線量の}

測定

独立行政法人国立病院機構九州循環器病センター 天川一利

瀬口良子，渋谷 充，坂元成行，野村尚史，折田信一

【日的】血管造影領域においてX線装置の性能向上，手技の進歩によ る治療の増加，さらに透視時間の延長に伴い放射線皮虚障害の報告 が増加している．今回，X線照射により発色する反射型線量測定用 フィルムを入手し, さらに放射線治療精度管理で実績のある濃度線 量変換システム (DD-System)を利用することで, 今まで予測不可能 であった経皮的冠動脈インターベンション(PCI) における患者の局 所被ばくについて明らかにする。

【方法】当院で施行したPCI 108症例 [右冠動脈 (RCA) $(n=30)$, 左前下 行枝 (LAD) ( $n=48)$, 左回旋枝 ( $\mathrm{LCX})(\mathrm{n}=24)]$ に対して反射型線量測 定用フィルムを患者の背中に敷き, DD-Systemを用いて最大皮膚線 量(MSD)の位置と線量について調べた。

【結果】1. PCIを行う冠動脈と局所被ばくの位置についてRCA, LAD，LCXにそれぞれPCIを行った症例でMSDの位置に違いがある かを $\chi^{2}$ 検定(フィッシャー直接確率試験)で調べた結果, 有意差 ( $<<0.01)$ が認められた．2．PCIを行う冠動脈と局所被ばくについて PCIを行う冠動脈とMSDに有意差[Kruskal-Wallisの順位検定法 $(\mathrm{p}<0.01)]$ が見られ, さらに多重比較検定の結果, RCAとLAD及び RCAとLCX を比較した場合にのみ有意差 $(\mathrm{p}<0.01)$ が見られた。

【結論】PCIを行う冠動脈に応じてMSDの位置が異なっており，ある 程度, 予測可能であることが判明した。また, RCAにPCIを行った 症例は, LADやLCXにPCIを行った症例に比べてMSDの值が高く, 皮䖉障害が発生しやすく注意が必要であることが示唆された。

121 I.IおよびX線管焦点一被写体間距離，およびFIDの違いによ る患者皮䖉入射線量低隇効果の違い

医療法人仁明会齋藤病院・放射線部 小野寺理紗，高野正彦 東北大学・医学部保健学科放射線技術科学専攻 千田浩一 東北厚生年金病院·中央放射線部森嶋貴顕, 千葉浩生, 佐藤咲子 【目的】血管造影，IVRによる放射線障害が問題視されるなか，患者 の被曝線量をいかにして減らすかが大きな課題である.I.Iと被写体 を密着させることは最も簡単な線量低減法であるが, 今回I.I面と被 写体間に距離がある場合，「寝台を上げて密着させることで得られる 被曝低減効果」と「I.I面を下げて密着させた場合の低減効果」を詳細に 比較した。

【方法】被写体にアクリルファントムを使用し，その入射線量をSkin Dose Monitorで測定した．X線装置は心血管撮影装置「東芝KXO-80C」 を使用し，撮影，透視条件はAutoに設定した. I.I〜被写体間を $5 \mathrm{~cm}$ 
及び10cm離した状態での線量を基準とし，「I.I面を下げて被写体に 密着させた場合 (FIDを短くする)」と，「寝台を上げてI.I面に被写体を 密着させた場合 (X線管焦点一被写体間距離を離す)」の線量を測定 し, 線量低減効果を比較した。測定は，FID，I.Iインチサイズ，ア クリルファントム厚さを変化させて，詳細に行った。

【結果】種々の条件, 諸因子によって線量低減の度合いは異なってい た. I.I〜被写体間が $5 \mathrm{~cm}$ 離れている場合, 被写体にI.I面を近づける と最大で14\%の線量が低減したが，葠台を上げて被写体をI.I面に近 づけた場合, 最大で $21 \%$ 線量低減効果が得られた。 またI.I〜被写 体間が $10 \mathrm{~cm}$ の場合は，寝台を上げて被写体をI.I面に近づける事で最 大 $37 \%$ の線量低減効果が得られた.

【結論】検查中，I.I〜被写体間が離れている際は，I.Iを下げるよりも 可能な限り寝台を上げて密着させる事で良好な線量低減効果が得ら れた.

122 アブレーション時の患者右腕の被ばく線量について NTT東日本関東病院·放射線部 松村昌希, 中西雄一, 福地達夫 塚本篤子, 若松 修

【目的】不整脈治療であるアブレーションでは，透視時間が長く，撮 影回数も多くなるため, 総線量はPCIより多くなることさえある. 当院ではアブレーション時に患者右腕を挙上しないため, X線管に 最も近い右腕の被ばく線量について測定したので報告する。

【方法】アブレーションは検査時間が長くかかるため患者右腕の挙上 はせず，透視・撮影の角度と絞りにより右腕が照射野に入らないよ うにしている．測定は，アブレーション時に患者右腕にSKIN DOSE MONITOR (SDM)のデイテクタをつけて計測した。当院の心臓力 テーテル装置には, 面積線量計が装着されているので, その值との 関係も考察する.

【結果】2003年 4 月から 2005年 3 月までのアブレーション129件の平 均値は, 検査時間198分, 透視時間92分, FPD (焦点-被写体間距離)

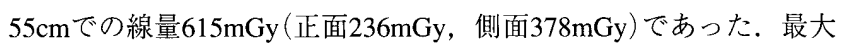
值は2794mGy (正面 $1140 \mathrm{mGy}$ ，側面 $1720 \mathrm{mGy}$ )であった．右腕が照射 野に入っていると仮定すると, FPD45cmとして1.4倍の線量が照射さ れることとなり，側面では最大值の場合 $3 \mathrm{~Gy}$ 超えることが予想さ れる。. 今回，透視・撮影角度と絞りにより照射野に入らないように した場合，総線量の約 $5 \%$ 以内, 側面の線量の約 $7 \%$ 以内の結果で あった.アブレーション時は, 透視のパルスレート, 線量率, I.I.サ イズなどを低被ばく設定として被ばく低減に努めているが，右腕に 関しては照射野に入らないようにすることが一番の被ばく低減方法 である。

123 未破裂動脈瘤コイル塞栓術における被曝線量の実態と低減対 策

東京慈恵会医科大学附属病院・放射線部 庄司友和，小原貴之

山下慎一，平松雅樹，羽染秀樹，矢本俊一

【目的】当院の脳動脈瘤に対する第一選択はコイル塞栓術としてい る. 前回の総会にて当院の動脈瘤コイル塞栓術における放射線被曝 の実態を報告したが, 実際の治療時はかなりの透視時間を必要とす るため放射線障害を未然に防ぐのは非常に困難と言える。 その後も コイル塞栓時の被曝線量測定を行ったが，その殆んどが約 $1 \mathrm{~Gy}$ 優 に超していることがわかった。 よって今回, 未破裂動脈瘤コイル塞 栓術に対する被曝線量の実態を分析し, 得られた結果から被曝低減 対策の立案を目的とした。

【方法】未破裂動脈瘤コイル塞栓術の一連の手技を標準化し, それら に対して実際の治療中の線量分布図と経時的線量変化グラフより各 手技に対する分析を行い，具体的な被曝低減対策を導き出した．

【結果・考察】今回，様々なデー夕を分析したことにより実際の手技 中の被曝低減対策や一連の手技の改善点などをグラフなどを用いて
明確に表すことが出来た. 特にアプローチアングル決定後の照射野 の大きさやカテーテルテーブルの高さなどの設定に関しては，十分 な配慮を行えば脳動脈瘤コイル塞栓術に招ける理想の放射線防護を 行えることが分かった。今後は定期的なカンファレンスなどを設 け，実際の手技中の被曝低隇ポイントや改善策などを啓発し，技師 と術者とが協力して放射線障害に立ち向かっていくべきと考える.

124 小览IVRにおける被曝線量簡易算出システムの作成 兵庫県立こども病院・検查 ·放射線部 関尾直士, 廣瀬悦子 北住一哉，正井秀幸，田淵仁春

【目的】近年，IVRの発展は小児科領域においても目覚しく，手術が 必要であった症例もIVRによって治療が可能となってきた。しか し，同時にIVRによる被嚗線量の増大が懸念されており，特に感受 性が高い小児の被曝管理は重要な問題である. 当院装置には被曝線 量監視ソフトが搭載されておらず, 被曝線量の管理が十分には行え ていない. 今回, IVR時に被曝線量を把握して施行医に知らせ, 検 查後に被曝線量の管理を行うことを目的として簡易算出システムを 作成したので報告する。

【方法】IIVRに扔ける患者皮膚線量の測定マニュアル」に従い線量測 定を行った．小児は体厚の差が大きいため，水ファントムの深さを $5 \sim 20 \mathrm{~cm}$ の間で $5 \mathrm{~cm}$ ごとに変化させ透視と撮影の吸収線量率を測定 した，照射野サイズを変化させ，正面と側面の測定を行った，得ら れた測定結果より被曝線量を算出する簡易ソフトをPC上に作成し た。

【結果】実測により得られた透視線量 $(\mathrm{Gy} / \mathrm{min})$, 撮影線量 $(\mathrm{Gy} / \mathrm{sec})$ に，検査時の透視時間，撮影時間を入力することで，被曝線量の算 出が可能になった，算出した被曝線量をIVR施行医に知らせた．被 曝線量が $1 \mathrm{~Gy}$ 超えた場合にはカルテに線量を記入し, 主治医より 保護者に対し，皮膚への影響の可能性についての説明を行うように した.

【考察】作成した簡易算出システムによってIVR時の被曝線量が把握 でき，線量管理が可能となった，検査中に線量経過をIVR施行医に 知らせることが可能なため, 被曝低減のための術式選択など検查プ ランニングの参考になると考える。しかし，装置の幾何学的配置に よって多様に変化する被曝線量を正確に算出することは今回の算出 システムでは困難であり，今後の検討課題としたい。

125 頭部血管撮影領域における面積線量計の指示值の有効活用 藤田保健衛生大学病院·放射線部高井洋次, 小林正尚, 佐藤 保 荒川伸二, 伊藤勝祥，小林謙一，北澤英俊 藤田保健衛生大学・衛生学部診療放射線技術学科鈴木昇一

【目的】当院での頭部血管内治療件数は年々増加傾向にあり, 平成 16 年度においては約 120 件に及んだ，その中には一時脱毛を認める症 例も報告されており, 患者皮層表面入射線量を把握, 管理する必要 がある、昨年度新規に導入された血管撮影装置Phillips社製 Integris Alluraは内蔵された面積線量計によって検査中の面積線量值(以下 DAP值)がリアルタイムに表示されるが，この值は直感的に理解し づらい. Skin Dose Monitor (以下SDM) を用いて入射表面線量を測定 し, DAPからの変換係数を求め, 有効利用したので報告する.

【使用機器】Phillips Integris Allura 固有万過 $2.5 \mathrm{mmAl}(100 \mathrm{kV})$ I.I.15inch, Skin Dose Monitor Mc MAHON Medical Model 104-101, Sensor TYPE 104-120, 頭部ファントム, 頭部用フィルター0-12mAl 【方法】頭部ファントムを用いて, 通常頭部血管撮影で使用されるポ ジション(正面：頭尾方向20度, I.I.-Size：10inch, 側面：I.I.-Size： 12inch)での入射表面，中央にSDMを配置し，透視および撮影時の DAP值とSDM指示值の関係を調べる，放射線の確定的影響を考慮 し，しきい值線量とDAPとの関係をグラフ化し揭示する。

【結果】DAP值 $1 \mathrm{Gycm} 2$ はSDM值4.23mGyに相当する. 放射線の確定 